\title{
Increase Helianthus annuus L. Tolerance and Accumulation of Cadmium In Vitro and it's Expression in Intact Plants
}

\author{
Zainab F. Mahmood ${ }^{1 *}$ and Kadhim M. Ibrahim ${ }^{2}$ \\ ${ }^{1}$ College of Science, Baghdad University. \\ ${ }^{2}$ College of Biotechnology, Al-Nahrain University. \\ *Corresponding Author: Zainab.farqad@gmail.com
}

\begin{abstract}
An experiment was carried out to study cadmium tolerance at the tissue culture and whole plant levels of Helianthus annuus. Callus was initiated and maintained on Murashige and Skoog medium (MS) supplemented with $0.2 \mathrm{mg} . \mathrm{L}^{-1}$ Kinetin (KIN), $0.4 \mathrm{mg} . \mathrm{L}^{-1}$ Naphthalene acetic acid (NAA) and $0.5 \mathrm{mg} . \mathrm{L}^{-1} 2,4$ - dichlorophenoxy acetic acid (2,4-D) using hypocotyls explants for callus induction. Different concentrations of cadmium were added directly to the culture medium as a contaminants. Selected tolerant cell lines were subjected to regeneration. The concentration of cadmium accumulated in callus tissues recorded $18 \mathrm{ppm}$ at $2.0 \mathrm{mg} . \mathrm{L}^{-1}$ of $\mathrm{Cd}$. The study included the effect of the cytokinin Benzyl adenine (BA) and the auxin NAA on the number of regenerated shoots percentage from tolerant callus to $\mathrm{Cd}$. Results exhibited that $71 \%$ of callus tolerant to $\mathrm{Cd}$, when the combination of $1.0 \mathrm{mg} . \mathrm{L}^{-1} \mathrm{BA}$ and $0.5 \mathrm{mg} . \mathrm{L}^{-1} \mathrm{NAA}$ was supplemented to the medium. The effect of NAA on rooting of shoots showed that the concentration $2.0 \mathrm{mg} . \mathrm{L}^{-1}$ of NAA gave rooting percentage mounted to $66 \%$. The study also included measurement of plant height and fresh weight. Maximum Cd accumulation reached $12.2 \mathrm{ppm}$ in the shoots. Tolerance to $\mathrm{Cd}$ seems to express in the plant shoots according to the current study. [DOI: $\underline{10.22401 / J N U S .20 .2 .13}$ ]
\end{abstract}

Keywords: Helianthus annuus, Cd tolerance, tissue culture, phytoremediation, regeneration.

\section{Introduction}

Sunflower (Helianthus annuus L.) is an annual plant of genus Helianthus grown as a crop for its edible oil and the endosperm of seeds. Sunflower is also used as bird food, as livestock forage (as a meal or a silage plant), and used in some industrial applications. It is also used in soil cleaning due to its moderate tolerance capability to different types of heavy metals (1).

Plant survival under adverse environmental conditions relies on integration of stress adaptive metabolic and structural changes in plants including abiotic environmental factors such as heavy metals. Some manmade activities like irrigation with sewage sludge, adding fertilizers, and the discharge of domestic wastes in land were the main source of soil and water contamination. Pollution with heavy metals is common in industrial cities, in the air, soil and water and poses many problems causing adverse effects on ecosystems and a risk to human health. It can enter the food chain through contaminated drinking water or agricultural products.
Contaminants alter soil properties biomass, fertility, crop yield and thus the human health (2). Toxicity with heavy metals reflects its impact on plant growth including leaf chlorosis, a decrease in the rate of seed germination, and a crippled photosynthetic apparatus, often correlated with plant death. Phytoremediation technology provides solution to this critical problem which is considered a safe and cheap method for the removal of these pollutants (3).

Tissue culture is a powerful tool that provides the possibility for growing millions of cells under controlled conditions, and to get physiological information about the behavior of the plant cells under stress conditions. Screening and selection at the plant cell level has established plants with increased tolerance to various environmental stresses like salt, drought, diseases, herbicides and heavy metals (4).

Due to the widespread of heavy metals contamination in soils as a result of industrial activities, thus this project was designed to investigate the ability of $H$. annuus to tolerate $\mathrm{Cd}$, screening and selection tolerant cell 
lines and develop a regeneration protocol to whole plants and estimation of $\mathrm{Cd}$ in the vegetative and root systems of the plants raised from tissue culture. This may lead to select sunflower plants exhibit increased tolerance to $\mathrm{Cd}$.

\section{Materials and Methods}

Seed sterilization: Seeds of $H$. annuus were washed with tap water and then surface sterilized with $70 \%$ ethanol followed by washing with sterile distilled water three times, then they were sterilized with $50 \%(\mathrm{v} / \mathrm{v})$ chlorex $(6.25 \%$ sodium hypochlorite) with a drop of tween-20 for 30 minutes. Finally they were washed with sterile distilled water for three times. All steps of sterilization were carried out under aseptic conditions using laminar air flow cabinet. Seeds were transferred to petri dishes containing sterile filter paper to remove excess water (5).

Ready-made MS medium: Murashige and Skoog (MS) medium components (6) were used according to the manufacture instructions. A quantity of $4.99 \mathrm{~g}$ of the powder medium was dissolved in one liter of distilled water supplemented with $30 \mathrm{~g} / \mathrm{L}$ sucrose and growth regulators at different concentrations. The $\mathrm{pH}$ of the medium was adjusted to 5.8 , then $7 \mathrm{~g} / \mathrm{L}$ agar was added to the medium. The medium was dispensed in universal tubes $(8 \times 2.5) \mathrm{cm} 10 \mathrm{ml} /$ tube. The culture medium was autoclaved at a pressure of $1.04 \mathrm{Kg} . \mathrm{cm}^{-2}, 121^{\circ} \mathrm{C}$ for $15 \mathrm{~min}$., and then left at room temperature until use.

Raising of seedlings: Surface sterilized seeds were germinated in universal tubes $(8 \times 2.5) \mathrm{cm} /$ tube on hormone free MS medium, and then incubated in a growth chamber under total darkness at $25^{\circ} \mathrm{C}$ for 5-7 days.

Callus induction and maintenance: The seedlings were transferred to sterilized petri dishes under sterile conditions, the hypocotyls were cut into $0.5 \mathrm{~cm}$ explant and inoculated into callus induction medium containing 0.5 mg.L ${ }^{-1} \quad 2,4-\mathrm{D}, \quad 0.4 \mathrm{mg} . \mathrm{L}^{-1} \quad \mathrm{NAA}$ and $0.2 \mathrm{mg} . \mathrm{L}^{-1} \mathrm{KIN}$. Explants were cultured with 10 replicates for each treatment; cultures were incubated at $25 \pm 2^{\circ} \mathrm{C}$ at 1000 lux light intensity for $16 / 8 \mathrm{hrs}$ light/darkness. Results were recorded after four weeks of incubation (7). Small pieces of calli weighting $50 \mathrm{mg}$ were transferred into fresh MS medium supplemented with the same hormonal combination used for callus induction after four weeks. This medium was suitable for maintaining calli for the next experiment.

\section{Inoculation of callus cultures to a medium} containing Cd: Different concentrations (0.0, 1, 2, 3, 4 and 5) ppm of $\mathrm{Cd}$ were added to the maintenance medium. About $100 \mathrm{mg}$ of fresh weighted calli were subcultured directly onto the prepared medium. Callus fresh weights were recorded after four weeks and recultured three times on the same medium. Each treatment was carried out with 10 replicates.

\section{Determination of $\mathbf{C d}$ callus cultures: Before} digestion, samples were dried at $65^{\circ} \mathrm{C}$ for $48 \mathrm{hrs}$. One gram of the sample was placed in a $250 \mathrm{ml}$ digestion tube and aliquot of $10 \mathrm{ml}$ concentrated $\mathrm{HNO}_{3}$ was added to the mixture and then gently boiled for $30-40 \mathrm{~min}$. to oxidize all easily oxidizable materials. After cooling, aliquot of $5 \mathrm{ml}(70 \%) \mathrm{HClO}_{4}$ was added and the mixture was boiled gently until dense white fumes appeared. After cooling, $20 \mathrm{ml}$ of distilled water were added and the mixture, boiled further to release any fumes. The solution was cooled, further filtered through $0.4 \mu \mathrm{M}$ Millipore filter, then transferred to a $25 \mathrm{ml}$ volumetric flask. The $\mathrm{Cd}$ was estimated by flame atomic absorption spectrophotometer (8).

Selection of $\mathrm{Cd}$ tolerant cell lines: The concentration of $\mathrm{Cd}$ at $2.0 \mathrm{ppm}$ was considered under the lethal dose hence tolerant cell lines can be selected. These Cd tolerant cell lines were recultured on MS free medium then transferred to MS medium containing the same $\mathrm{Cd}$ concentration for further confirmation.

Determination of callus relative fresh weight (RFW): Relative fresh weight of the callus initiated on hypocotyl explant was recorded at different concentrations of $\mathrm{Cd}$ and calculated according to the following formula (9).

$$
\mathrm{RFW}=\frac{\mathrm{FWF}-\mathrm{FWI}}{\mathrm{FWI}}
$$


where FWI = initial callus fresh weight; $\mathrm{FWF}=$ final callus fresh weight.

\section{Regeneration}

Shoot regeneration from $\mathrm{Cd}$ tolerant cell lines: Tolerant calli were selected and transferred into the regeneration medium under aseptic conditions. The regeneration medium consisted of full strength MS medium supplemented with BA $(0.0,0.5,1.0,1.5$ or 2.0) $\mathrm{mg} . \mathrm{L}^{-1}$ and NAA $(0.0,0.3,0.5,0.7$ or 1.0$)$ $\mathrm{mg} \cdot \mathrm{L}^{-1}$. All cultures were maintained at $25 \pm 2^{\circ} \mathrm{C}$ for $16 / 8 \mathrm{hrs}$ (light/dark) photoperiod with a light intensity of 1000 lux.

Root regeneration from Cd tolerant cell lines: Shoots were transferred into the same regeneration medium except the replacement of plant growth regulators with $2 \mathrm{mg} / \mathrm{L}$ NAA only (10).

Determination of $\mathbf{C d}$ in plantlets (ppm): $\mathrm{Cd}$ was determined in the vegetative and root tissues separately after drying in an oven depending on the method described by (11).

\section{Results and Discussion}

Callus induction, maintenance and dry weights: Callus was initiated and maintained on MS medium supplemented with $0.5 \mathrm{mg} . \mathrm{L}^{-1}$ 2,4-D, $0.4 \mathrm{mg} . \mathrm{L}^{-1}$ NAA plus $0.2 \mathrm{mg} . \mathrm{L}^{-1} \mathrm{KIN}$ as has been described by (7). This combination was reexamined by the researcher to confirm that the above medium is convenient for callus initiation and maintenance under the experimental conditions in our laboratories; results are summarized in Tables (1) and (2).

Table (1)

Percentage of callus induction on $H$. annuus hypocotyl explants cultured on MS medium supplemented with $0.5 \mathrm{mg} . \mathrm{L}^{-1} 2,4-\mathrm{D}, 0.4$ mg. $L^{-1} \mathrm{NAA}$ and $0.2 \mathrm{mg} . \mathrm{L}^{-1} \mathrm{KIN}$ after four weeks, $n=10$.

\begin{tabular}{||c||c|}
\hline Treatment & Callus induction (\%) \\
\hline \hline $\begin{array}{c}\text { MS free } \\
\text { hormones }\end{array}$ & 0.0 \\
\hline $\begin{array}{c}\text { MS + plant } \\
\text { hormones }\end{array}$ & 100 \\
\hline
\end{tabular}

The addition of auxins and cytokinins are important for callus induction, since cytokinins work as a key for cellular division in the presences of auxins. Inclusive of 2,4-D, NAA and KIN at certain combinations to MS medium could be the key for good callusing on hypocotyl explants. In order to maintain and increase callus mass, portions of calli obtained from previous experiment were transferred to MS medium supplemented with the same combination of plant growth regulators. Harvested callus gave $650 \mathrm{mg}$ fresh weight and $122 \mathrm{mg}$ dry weight Table (2).

Table (2)

Callus fresh and dry weights (mg) grown on MS medium supplemented with $0.5 \mathrm{mg} . \mathrm{L}^{-1}$ of 2,4-D, 0.4 mg. $L^{-1}$ of NAA and $0.2 \mathrm{mg} . \mathrm{L}^{-1}$ of KIN after four weeks. Initial callus fresh weight was $35 \mathrm{mg} . \mathrm{n}=10$.

\begin{tabular}{|c||c||c||}
\hline Treatment & $\begin{array}{c}\text { Fresh weight } \\
\text { (mg) }\end{array}$ & $\begin{array}{c}\text { Dry weight } \\
\text { (mg) }\end{array}$ \\
\hline \hline $\begin{array}{c}\text { MS free } \\
\text { hormones }\end{array}$ & 0.0 & 0.0 \\
\hline $\begin{array}{c}\text { MS + plant } \\
\text { hormones }\end{array}$ & 650 & 122 \\
\hline
\end{tabular}

Effect of Cd on callus RFW: Callus cultures were inoculated into MS medium containing different concentrations $(0.0,1.0,2.0,3.0,4.0$ or 5.0) ppm of $\mathrm{Cd}$ to investigate their expected adverse effect on callus RFW. It is clear from the results shown in Table (3), that the highest callus RFW occurred at $\mathrm{Cd}$ concentration $2.0 \mathrm{ppm}$ recording $2 \mathrm{~g}$. Callus RFW decreased with increasing concentrations of $\mathrm{Cd}$ reaching $1.10,0.90$ and $0.20 \mathrm{~g}$ respectively at 3.0, 4.0 and $5.0 \mathrm{ppm}$. All means were not significantly different compared to the control treatment $(1.6 \mathrm{~g})$ except a significant reduction in RFW occurred at the 4.0 and $5.0 \mathrm{ppm}$. Shekhawat et al. (12) stated a reduction in callus fresh weight with the increase of $\mathrm{Cd}$ in calli of Brassica. Similar findings were reported by (4) in soybean (Glycine max) cultures, while callus relative fresh weight increased at low $\mathrm{Cd}$ concentrations. This could be explained by the competition between $\mathrm{Zn}$ or $\mathrm{Fe}$ and $\mathrm{Cd}$ for the same cellular binding sites since there is similarity in structural and environmental properties and can functionally substitute $\mathrm{Zn}$ in plant cells. 
High concentrations of $\mathrm{Cd}$ result in toxicity represented by various functionalbased alterations in plants such as growth retardation, changes in root morphology, root and leaf anatomy, and damages to cell structures as well as disturbance in water balance, mineral nutrition, photosynthesis, and plant development $(13,14)$.

Table (3)

Effect of cadmium on callus RFW after culture on maintenance medium. Initial callus fresh wt. $100 \mathrm{mg} . n=10 . \pm$ represents standard error for mean values.

\begin{tabular}{|c||c|}
\hline $\begin{array}{c}\text { Cd Conc. } \\
\text { (ppm) }\end{array}$ & $\begin{array}{c}\text { Callus RFW } \\
\text { (g) }\end{array}$ \\
\hline \hline 0.0 & $1.60 \pm 0.06$ \\
\hline 1.0 & $1.77 \pm 0.11$ \\
\hline 2.0 & $2.00 \pm 0.06$ \\
\hline 3.0 & $1.10 \pm 0.09$ \\
\hline 4.0 & $0.90 \pm 0.02$ \\
\hline \hline 5.0 & $0.20 \pm 0.06$ \\
\hline \hline L.S.D: 0.05 & 0.639 \\
\hline
\end{tabular}

Quantitation of $\mathrm{Cd}$ in callus tissues: Accumulated $\mathrm{Cd}$ in hypocotyl derived callus was determined spectrophotometry. The accumulation effect of different $\mathrm{Cd}$ concentrations on callus tissues is represented in Table (4); all Cd treatments caused significant increase in $\mathrm{Cd}$ when compared to the control treatment. The highest accumulation level was found at $2.0 \mathrm{ppm}$ of $\mathrm{Cd}$ concentration recording $18 \mathrm{ppm}$, the increase in $\mathrm{Cd}$ concentration resulted in a decrease in the accumulation levels recording 15,10 and $7 \mathrm{ppm}$ at 3.0, 4.0 and $5.0 \mathrm{ppm}$ respectively. High $\mathrm{Cd}$ concentration may decrease antioxidative enzyme activities which is congruent with the decrease in membrane integrity leading to cells toxicity and eventually their death (15).
Table (4)

Cadmium accumulation (ppm) in H. annuus callus tissues after treatment with different concentrations of Cd after four weeks of culture.

\begin{tabular}{|c|c|}
\hline Cd conc. $(\mathbf{p p m})$ & Accumulated Cd (ppm) \\
\hline \hline 0.0 & 0.0 \\
\hline 1.0 & 13 \\
\hline 2.0 & 18 \\
\hline 3.0 & 15 \\
\hline 4.0 & 10 \\
\hline 5.0 & 7 \\
\hline \hline Mean & 10.5 \\
\hline \hline L.S.D. 0.05 & 3.88 \\
\hline \hline
\end{tabular}

Shoot regeneration: Results exhibited that MS medium supplemented with BA at 1.0 and $0.5 \mathrm{mg} . \mathrm{l}^{-1}$ NAA gave the highest shoot formation percentage reached $90 \%$ for control, while $71 \%$ in calli tolerated $2.0 \mathrm{ppm}$ of $\mathrm{Cd}$ Table (5). No shoots formed neither in the absence of BA and NAA nor at high concentrations of BA (2.0) and $1.0{\mathrm{mg} . \mathrm{l}^{-1}}^{-1}$ NAA. This indicates a synergistic relation between auxins and cytokinins promoting tissues differentiation with the preference of higher cytokinin level over the auxin (3). Similar results are also reported by (16) who obtained good shoot regeneration from sunflower callus cultures when $1 \mathrm{mg} / \mathrm{l} \mathrm{BA}$ and $0.5 \mathrm{mg} / \mathrm{l} \mathrm{NAA}$ were added to the medium. Presence of cytokinins at relatively high level accompanied with low level of auxins promotes shoots initiation and multiplication. Results also showed no shoot formation at high levels of BA and NAA. This may be due to the negative effect of NAA on callus response to regenerate shoots. 
Table (5)

Shoot formation percentage from cadmium tolerant calli grown on MS medium supplemented with different concentrations of $B A$ and NAA. After four weeks. $n=10$.

\begin{tabular}{|c||c||c||c|}
\hline $\begin{array}{c}\text { BA } \\
\left(\mathbf{m g . l ^ { - 1 }}\right)\end{array}$ & $\begin{array}{c}\text { NAA } \\
\left(\mathbf{m g . l}^{\mathbf{1}}\right)\end{array}$ & $\begin{array}{c}\text { Non- } \\
\text { treated }\end{array}$ & $\begin{array}{c}\text { Shoot formation } \\
\text { \% } \\
\text { from Cd tolerant } \\
\text { callus }\end{array}$ \\
\hline \hline 0.0 & 0.0 & 0.0 & 0.0 \\
\hline \hline 0.5 & 0.3 & 81 & 53 \\
\hline 1.0 & 0.5 & 90 & 71 \\
\hline 1.5 & 0.7 & 68 & 16 \\
\hline \hline 2.0 & 1.0 & 0.0 & 0.0 \\
\hline \hline \multicolumn{2}{|c|}{ mean } & 48.0 & 28.0 \\
\hline
\end{tabular}

Rooting of regenerated shoots: Elongated and healthy shoots were transferred to a rooting medium consisted of MS medium supplemented with $2.0 \mathrm{mg} .1^{-1} \mathrm{NAA}$ as has been described by (10). Root formation varied depending on the origin of callus derived shoots, when $2.0 \mathrm{mg} . \mathrm{l}^{-1}$ NAA was added to the medium Table (6). The highest percentage of rooting was $90 \%$ in the $\mathrm{Cd}$ free callus, $66 \%$ in shoots derived from $\mathrm{Cd}$ tolerant calli which is considered to be very high.

\section{Table (6)}

Root formation percentage of cadmium tolerated callus and untreated callus grown on MS medium supplemented with $2 \mathrm{mg}^{-1}$ NAA after six weeks.

\begin{tabular}{|c||c|}
\hline Treatment & $\begin{array}{c}\text { Root formation } \\
\text { \% }\end{array}$ \\
\hline \hline $\begin{array}{c}\text { Untreated } \\
\text { callus }\end{array}$ & 90 \\
\hline Cd tolerated & 66 \\
\hline
\end{tabular}

Effect of Cd on $H$. annuus plantlets heights, shoot and root fresh and dry weights: A negative effect of $\mathrm{Cd}$ on the fresh and dry weight of shoots and roots was recorded. The highest shoots fresh weight was $7.9 \mathrm{~g}$ at the control and $6.6 \mathrm{~g}$ at $2.0 \mathrm{ppm}$ for plantlets derived from $\mathrm{Cd}$ tolerant callus Table (7). Root fresh weights were 3.7 and $4.3 \mathrm{~g}$ for the control and $2.0 \mathrm{ppm} \mathrm{Cd}$ concentration. Shoot dry weights recorded 3.5 and $3.1 \mathrm{~g}$ for the control and plantlets derived from $\mathrm{Cd}$ tolerant callus respectively. However, root dry weights reached 2.2 and $2.6 \mathrm{~g}$ in control and plantlets derived from $\mathrm{Cd}$ tolerant callus. Results also showed a significant reduction in plantlets heights, the highest was $13.9 \mathrm{~cm}$ in control and $9.3 \mathrm{~cm}$ in plantlets derived from $\mathrm{Cd}$ tolerant callus. The decrease in fresh weight of shoots in plantlets derived from $\mathrm{Cd}$ tolerant callus may be due to the slow movement of $\mathrm{Cd}$ ions inside the plant tissues causing accumulation in these tissues which results in weak plant growth and eventually plant toxicity (17).

Table (7)

Effect of cadmium on the fresh, dry weight and height of $H$. annuus plantlets derived from Cd tolerated and untreated callus after 6 weeks of rooting.

\begin{tabular}{|c|c|c|c|c|c|}
\hline \multirow{2}{*}{$\begin{array}{c}\text { Cd Conc. } \\
(\text { ppm) }\end{array}$} & \multicolumn{2}{|c|}{ fresh wt. (g) } & \multicolumn{2}{|c|}{ Dry wt. (g) } & \multirow{2}{*}{$\begin{array}{c}\text { Height } \\
\text { (cm) }\end{array}$} \\
\hline & shoot & Root & shoot & Root & \\
\hline 0.0 & $\overline{7.9}$ & $\overline{3.7}$ & 3.5 & $\overline{2.2}$ & 13.9 \\
\hline 2.0 & 6.6 & 4.3 & 3.1 & 2.6 & 9.3 \\
\hline L.S.D: 0.05 & 0.82 & 0.49 & 0.47 & 0.31 & 2.69 \\
\hline
\end{tabular}


Accumulation of $\mathrm{Cd}$ in $\boldsymbol{H}$. annuus plantlets:

Table (8) shows a significant increase in $\mathrm{Cd}$ accumulation at $2.0 \mathrm{ppm}$ in plantlets tissue when compared to the control treatment; the highest accumulation level was in the shoots recording $12.2 \mathrm{ppm}$ while it recorded $9.7 \mathrm{ppm}$ in the roots. $\mathrm{Cd}$ is one of the toxic metals with slow movement capability in plant cells accumulates in roots. $\mathrm{Cd}$ accumulates in roots more than shoots; elevated levels of it may damage plant tissues. $\mathrm{Cd}$ is a no-redox metal that is strongly phytotoxic causing growth inhibition and plant death. Cd toxicity to plants causes alteration in membranes functionality by inducing changes in the lipids composition (18).

Table (8)

Accumulation of cadmium in shoots and roots of $H$. annuus plantlets derived from callus after 6 weeks of rooting.

\begin{tabular}{|c|c|c|}
\hline \multirow{2}{*}{ Cd conc. $(\mathbf{p p m})$} & \multicolumn{2}{|c|}{ Content (ppm) } \\
\cline { 2 - 3 } & Shoot & Root \\
\hline \hline 0.0 & 0.0 & 0.0 \\
2.0 & 12.2 & 9.7 \\
\hline \hline L.S.D: 0.05 & 3.66 & 2.65 \\
\hline
\end{tabular}

It has been concluded from the present work that $H$. annuus callus can be manipulated in vitro to increase tolerance to $\mathrm{Cd}$ in plantlets drived from selected cell lines. This gain in $\mathrm{Cd}$ tolerance can be expressed in plantlets regenerated from callus cultures and thus, it is possible to enhance $\mathrm{Cd}$ tolerance in $H$. annuus plants grown in the field. It seems that sunflower plants accumulate $\mathrm{Cd}$ in their vegetative parts and thus can be manipulated to be hyperaccumulator. Examination of progeny would be the key for evaluating the heritability of $\mathrm{Cd}$ in the next generation.

\section{References}

[1] Kenneth D., Rebecca A. and Loren H. "Adaptive introgression of abiotic tolerance traits in the sunflower Helianthus annuus", J. of New Phytol, 187(1), 230-239, 2010.

[2] Varsha-Mudgal N., Anurag M., Singh R. and Sanjay M., "Effect of toxic metals on human health", The Open Nutr. J., 3, 9499, 2010.
[3] Waoo A., Swati K. and Shujata G., "Comparative tissue culture studies on Lanta camara and Datura inoxia at heavy metal contaminated site and phytoremediation approach at industrially contaminated sites", Inter. J. of Adv. Biol. (IJAB), 1(1), 55-62, 2014.

[4] Tal M., "Selection for stress tolerance. In Handbook of Plant Cell Culture: Techniques for Propagation and Breeding. Macmillan Publishing Company", New York, 1, 461-488, 1983.

[5] Akbar S. and Azra Q., "Tissue culture of sunflower", Pak. J. Agric., 15(1), 153-160, 1994.

[6] Murashige T. and Skoog F., "A revised medium for rapid growth and bioassays with tobacco tissue culture", Physiol. Plant, 15, 473-497, 1962.

[7] Aurelia B., "Callus initiation and morphogenesis induction in somatic tissue culture of Helianthus annuus L.", Trcu. Mus. His., 22, 33-41, 2000.

[8] Zeng G., Fung C., Am J., Connell D., Monilith J., Tanabe S. and Lam P., "Mussel- based monitoring of trace metal and organic contaminants along the east coast of China using Perna viridis and Mytilus edulis", Envi. Pollu., 127(2), 203-216, 2004.

[9] Daud M., Sun Y. and Dawood M., "Cadmium- induced functional and ultrastructural alterations in roots of two transgenic cotton cultivars", J. of Haz. Mat., 161(1), 463-473, 2009.

[10] Pandurang C., Devindra S. and Srinath R., "Introduction of callus from various explants and regeneration of plantlets in sunflower (Helianthus annuus L.) VAR. APSH-H”, J. of Crop Sci., 3(3), 87-89, 2012.

[11] Achakzi A., Mojeed O. and Oladele J., "Effect of mycorrhizal inoculation on the growth and phytoextraction of heavy metals by maize grown in oil contaminated soil", Pak. J. Bot., 44(1), 221-230, 2012.

[12] Shekhawat G., Verma K., Jana S., Singh $\mathrm{K}$., teotia $\mathrm{P}$. and Prasad A. "In vitro biochemical evaluation of cadmium tolerance mechanism in callus and seedlings of Brassica juncea", Prot., 239(14), 31-38, 2010. 
[13] Al- Samarii S. A. and Ibrahim K. M., "In vitro and in vivo studies on heavy metals tolerance in Sesabana grandifora L.”, J. of Biotech. Res. Center, 3(2), 48-64, 2009.

[14] Lateef Z. M., "Investigating heavy metals tolerance in Ruta graveolens in vivo and in vitro", MSc. Thesis. Biotechnology Dept. College of Sci. Al-Nahrain Univ. Iraq, 2015.

[15] Helena A., Clora G. and Conceicao S., "Cadmium effects in sunflower membrane permeability and changes in Catalase and peroxidase activity in leaves and callus", J. of Plant Nut., 28 (12), 1-16, 2005.

[16] Ozyigit I., Nermin G. and Belma D., "Geno type dependent callus induction and shoot regeneration in sunflower (Helianthus annuus)", Afri. J. of Biotech., 6 (13), 14981502, 2007.

[17] Shahatha A. F., "Application of plant $\mathrm{t}$ issue culture and Glomus mossaes in bioremediation of lead, cadmium and salinity using Sesbania rostrata L.", plant. phD. Dissertation. Biology Dept. College of Sci. for Women. Baghdad Uni. Iraq, 2015.

[18] Israr M., Sahi S. and Jain,, J., "Cadmium accumulation and anti-oxidotive responses in the Sesbania drummondii callus", Archives of Enviro. Contam. Toxicol., 50 (1), 121-127, 2006. 